\title{
Floral scents experienced within the colony affect long-term foraging preferences in honeybees*
}

\author{
Andrés ARENAs**, Vanesa M. FERNÁNDEZ**, Walter M. FARINA \\ Grupo de Estudio de Insectos Sociales. Departamento de Biodiversidad y Biología Experimental, \\ IFIBYNE-CONICET, Facultad de Ciencias Exactas y Naturales, Universidad de Buenos Aires, Pabellón II, \\ Ciudad Universitaria (C1428EHA), Buenos Aires, Argentina
}

Received 30 July 2008 - Revised 1 September 2008 - Accepted 5 September 2008

\begin{abstract}
Food scents circulating inside beehives influence foraging preferences in the field. However, the persistence and nature of the prior experience that lead to this biased response remain unknown. To determine how long honeybees show a food preference after experiencing a scented food inside the colony, we offered sugar solution scented into beehives. After all the combs of the experimental colonies were replaced, the landing responses of foragers were quantified in a two-scented-feeder situation outside the colony. We also tested whether bees exposed to a volatile compound inside the hive preferred a feeder scented with this odor to an unscented one. Results support the conclusion that the offering of a scented food enhanced the bias to this odor, whereas the volatile compound exposure caused a reduced landing response towards the scented option. These results suggest that olfactory experiences occurring within the beehive can promote changes in foraging preferences for several days.
\end{abstract}

Apis mellifera / honeybee / olfactory learning / long-term memory / foraging choice

\section{INTRODUCTION}

The relevance of a particular stimulus as a predictor of reward strongly depends on the context in which it was experienced, determining, in turn, the strength and enduring effect on the behavioral outcome (Rescorla et al., 1985; Balsam, 1985; Sandoz et al., 2000). In insects, olfactory stimuli play an essential role in the choice of food sources. To optimize foraging, insects like honeybees learn to discriminate floral olfactory cues associated with a valuable reward from those that do not predict food (Menzel, 1999). However, odors are not learned exclusively in the field but also inside the nests, for example when the intake of scented food from foragers lead to biased foraging preferences of their nest mates

Corresponding author: W.M. Farina,

walter@fbmc.fcen.uba.ar

* Manuscript editor: Stan Schneider

** Both authors contributed equally to this work. in the field (e.g., for honeybees: von Frisch, 1923; Wenner et al., 1969; for bumblebees: Dornhaus and Chittka, 1999; for yellow jacket: Jandt and Jeanne, 2005; for ants: Roces, 1990).

In honeybees, during recruitment to scented food sources, hive mates associate the incoming liquid food with its odor mainly during mouth-to-mouth trophallactic contacts (Farina et al., 2005; 2007; Gil and De Marco, 2005; Grüter et al., 2006), obtaining information that might be used for the decision-making process during foraging. Prior experiences with food odors have also been studied in a foraging context after feeding the entire colony with scented sugar solution (Arenas et al., 2007). After this treatment a preference for a prior circulated food scent was observed in an operant context (i.e. landings at a food-choice device) up to 24 hours, even after all the stores of scented food were removed from the hive.

To evaluate if the foraging preference driven by scented food can be retained longer, 
we offered a scented sugar solution inside the hive and tested the foragers' landing responses on a food-choice device in which they must decide between the prior food-offered odor versus an unfamiliar one. Retention was monitored at different intervals ranging from a few hours to 11 days after the treatment. We also investigated the effect of olfactory cues presented within the hive environment as a volatile compound that was not associated with the reward. Precocious odor exposure shows an inhibitory effect to associate the pre-exposed odor with a reward in honeybee workers reared under laboratory conditions (Sandoz et al., 2000; Pham-Delègue et al., 1990). However, after exposing a hive to a volatile compound, no significant effect was detected on learning performance (Gerber et al., 1996), suggesting that passive olfactory exposure cannot be transferred to the classical context of the proboscis extension response (PER) setup.

With the aim to compare the behavioral implication of an odorant cue associated or not to the food circulating within the hive, we also tested foragers' landing responses in which bees had to choose between a feeder with the hive pre-exposed odor against an unscented feeder. We also evaluated the preferences of foragers with rewarded olfactory experience to the scented solution or to an unscented option. Results support the conclusion that both stimulations have relevant roles in foraging preferences.

\section{MATERIALS AND METHODS}

\subsection{Study site and animals}

Four colonies (H1, H2, H3 and H4) of European honeybees (Apis mellifera L.) housed in the apiary of the experimental field at the School of Exact and Natural Sciences of the University of Buenos Aires $\left(34^{\circ} 32^{\prime} \mathrm{S}, 58^{\circ} 26^{\prime} \mathrm{W}\right)$ were used in this study during the summer seasons of 2006, 2007 and 2008. Hive 1 and $\mathrm{H} 2$ were used in experiment 1 ; $\mathrm{H} 3$ was used in experiment 2a and H4 in experiment $2 b$. Experimental colonies were reduced to a four-frame Langstroth hive from ordinary commercial ones (about 10000 individuals) and kept only with limited stored honey to facilitate the acceptance of artificial food. The experiment was carried out in flight chambers, each containing one experimental colony fixed on one side. Flight chambers $(6 \times 3 \times 2 \mathrm{~m})$, which consisted of wooden structures with transparent polyethylene rectangular meshes hanging inside, prevented the interference caused by other bee colonies during testing periods. When no testing was being carried out, the flight chambers remained open and bees could forage freely outside.

\subsection{Olfactory stimulation}

\subsubsection{Scented food}

To establish a rewarded olfactory experience in experiments 1 and $2 \mathrm{a}$, we used the offering of scented food as a conditioning procedure (Arenas and Farina, 2008). Scented food, obtained by mixing $50 \mu \mathrm{L}$ pure odorant per liter of $1.8 \mathrm{M}$ sugar solution was offered by replacing a lateral honey frame for an in-hive feeder containing $1.5 \mathrm{~L}$ of scented sugar solution that was left in the hive for a four-day period. After this time, the empty in-hive feeders and all the honeycombs were removed and replaced with combs that have not been exposed to the test scent.

Phenylacetaldehyde (PHE) and Linalool (LIO), both natural floral compounds (Knudsen et al., 1993 obtained from Sigma-Aldrich, Steinheim, Germany), were used as the conditioned odor diluted in the sugar solution in $\mathrm{H} 2$ and $\mathrm{H} 3$, and $\mathrm{H} 1$ respectively.

\subsubsection{Scented environment}

To determine if foraging preferences were affected by a non-rewarded odor experience (i.e. an odor experienced as a volatile compound within the hive but not diluted in the sugar solution), H4 was exposed to PHE for five consecutive days (experiment $2 b$ ). To scent the environment inside the hive, $3 \mathrm{~mL}$ of the odor was constantly provided in two small Petri dishes placed on the bottom hive (20 $\mathrm{cm}^{2}$ evaporation surfaces). Both Petri dishes were placed in the bottom of the hive from outside and had a plastic mesh that covered them to prevent bees from touching the content). After the exposure, all the hive combs and even the wooden box of the hive were replaced to prevent odor contamination during non-stimulation periods. 


\subsection{Training procedure}

All experiments were carried out in two phases: a training phase and a testing phase. During the training phase, bees in each flight chamber were trained to forage at an artificial ad libitum feeder (training feeder) placed in the middle of a wooden platform (1.6 m long) six meters away from the entrance of the hive. Feeders used during training (and testing) were acrylic dishes $(6.5 \mathrm{~cm}$ high, $4 \mathrm{~cm}$ in diameter) inverted over a Plexiglas plate $(10 \mathrm{~mm}$ thick, $5.5 \mathrm{~cm}$ in diameter and with 16 grooves, $1 \times$ $1 \times 10 \mathrm{~mm}$ ) cut in a radial arrangement on one side. This feeder, containing 1.8 $\mathrm{M}$ unscented sugar solution, was presented in the flight chamber for $30 \mathrm{~min}$, four times a day, everyday during the experimental period. Bees trained to the feeder characteristics (shape, size, color, and location) were used to quantify preferences in the testing phase.

\subsection{Testing procedure}

During the testing phase, the training feeder was removed and two similar feeders (i.e. test feeders) were placed equidistantly to the hive, $1.3 \mathrm{~m}$ from each other. Trained bees approaching the middle of the wooden platform (searching for the missing training feeder) were counted accordingly to the testing feeder they chose for landing. Immediately after landings experimental bees were captured and eliminated in order not to be double counted. Testing events lasted $10 \mathrm{~min}$ and were performed four times a day after the training feeder was removed (Arenas et al., 2007). Testing feeders were scented by two glass Petri dishes $(1 \mathrm{~cm}$ high, $15 \mathrm{~cm}$ in diameter) containing a filter paper disk $(55 \mathrm{~mm}$ in diameter) soaked with a pure odor $(50 \mu \mathrm{L}$ pure odorant) placed below each feeder (Arenas et al., 2007). The duration of the testing phase and the situation used to evaluate foraging preferences (testing food choices in a two-scented-feeder device or in a scented-feeder vs. unscented-feeder device) depended on the experiment.

\subsubsection{Testing food choices in a two-scented-feeder device}

This testing procedure was carried out in experiment 1 . Tests were performed 3-8 hours after the removal of scented food stores (henceforth: $<1$ day) on days 4,8 and 11 . Foraging preferences either towards the odor offered inside the hive (LIO or PHE) or to an odor assumed to be unfamiliar (PHE or LIO; henceforth: novel odor) were recorded. In order to do this, we compared the number of bees landing on the testing feeders scented with LIO and PHE. Responses before stimulation were not recorded in the experiment because: (i) $\mathrm{H} 1$ and $\mathrm{H} 2$ were tested almost simultaneously (2-day delay between colonies), and (ii) the pure odor that scented the solution of one hive represented the novel odor of the other colony during testing. Thus, we were able to reliably compare the effects of the olfactory experiences without needing to use untreated colonies as control units. Observations were conducted at regular times during the day: 10, 12, 14 and $16 \mathrm{~h}$.

\subsubsection{Testing food choices in a scented-feeder vs. an unscented-feeder device}

This testing procedure was used to evaluate food preference in experiment 2 , where olfactory stimulation was offered through (i) the scented food (experiment 2a) or (ii) the scented environment (experiment $2 \mathrm{~b}$ ). Here, we recorded foraging preferences towards either the previously experienced odor (PHE-scented feeder) or to an unscented feeder. Since in these experiments we did not offer LIO-scented food to another hive, food preference was analyzed in time: before, during and after the offering of scented food. In addition, we recorded preferences when the testing feeder was scented with LIO (as a novel odor) against an unscented testing feeder. Both tests (the PHE-scented or LIO-scented feeder versus an unscented feeder) were carried out in turns. Thus, on a single testing day, the response towards PHE (or LIO) vs. an unscented odor was evaluated twice. Sometimes, a third or even a forth-testing event was required to obtain an acceptable sample size. Tests were carried out at regular times during the experiment: 2 and 1 days before, 2 and 4 days during, and 6 and 8 days after the initiation of the olfactory experience. Then, recordings obtained within each period were pooled.

\subsection{Statistics}

In experiment 1 , G-test $(\mathrm{G})$ for goodness of fit was applied to see whether the observed frequencies 
a)

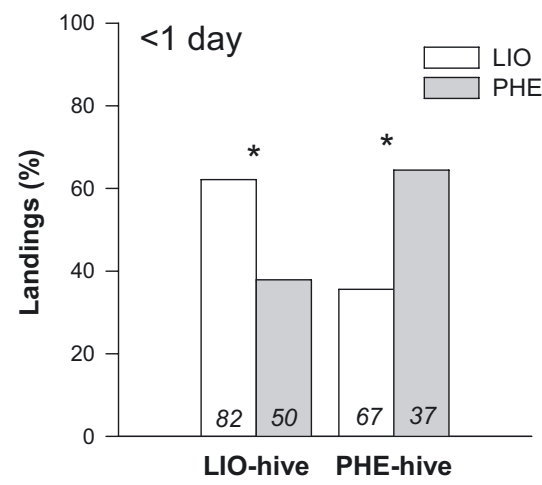

c)

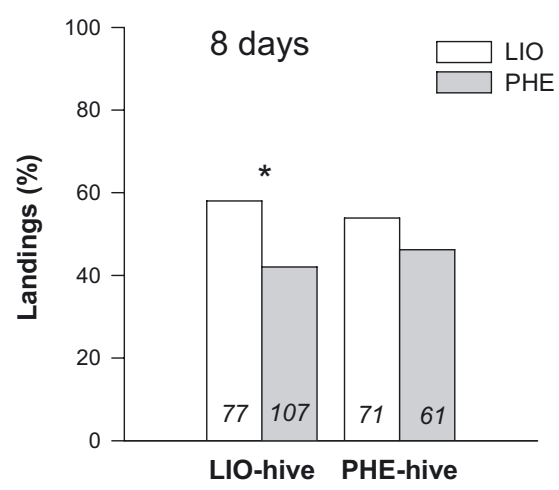

b)

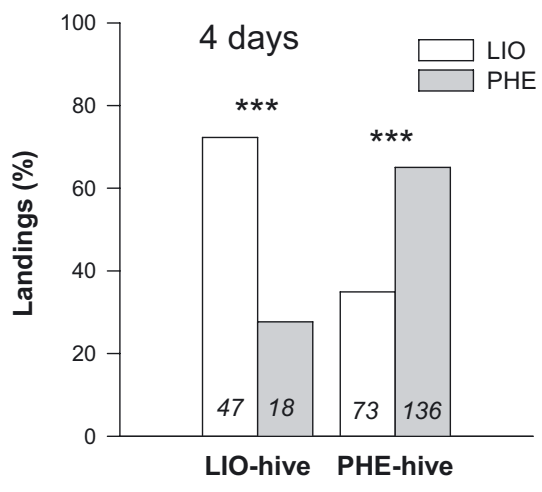

d)

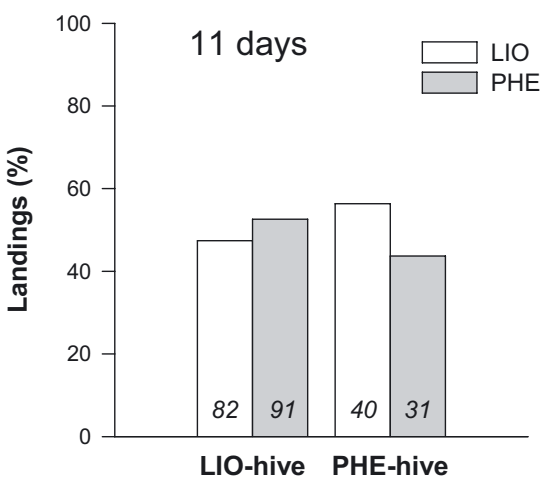

Figure 1. Percentages of landings carried out by honeybees at each testing feeder for different times after the removal of scented food stores (i.e. the removal of the in-hive feeder and the replacement of all the honeycombs). (a) Landings on each testing feeder during 4 ten-minute-observation periods for the first day after the removal ( $<1$ day), (b) for the fourth day, (c) for the eighth day and (d) eleventh day. Landings for LIO are presented in white bars and for PHE in gray bars. The number of bees landing on each feeder is shown at the bottom of each bar. Asterisks indicate statistical differences in G-Tests $(* P<0.05$, *** $P<$ 0.001; see Results for details).

of landing on LIO and PHE-scented testing feeders deviate significantly from random expected frequencies (50\% each one) (Sokal and Rohlf, 1995) for each testing day.

In experiment 2 the preferences between PHEscented and unscented testing feeders were compare over time (before, during and after) using the simultaneous-test procedure of the unplanned-test of homogeneity for goodness of fit. To carry out all possible comparisons between evaluation times, we used $\chi^{2} \alpha[(a-1)(b-1)]$ as a constant critical value $(a=2$ and $b=3)$.

\section{RESULTS}

\subsection{Experiment 1: Testing food choices in a two-scented-feeder device}

After the offering of scented food we observed a sustained preference for the treatment-odor feeder until the fourth day in both the LIO-scented and the PHE-scented hives ( $\mathrm{H} 1$ and $\mathrm{H} 2$ respectively; Fig. 1). Immediately after the removal of the food stores ( $<1$ day), the number of landings on the treatment-odor feeder was significantly higher 
than on the novel-odor feeder $(\mathrm{H} 1: \mathrm{G}=7.835$, $P=0.005$, df $=1, \mathrm{~N}=132 ; \mathrm{H} 2: \mathrm{G}=8.778$, $P=0.003, \mathrm{df}=1, \mathrm{~N}=104 ; \mathrm{G}-$ Test goodness of fit; Fig. 1a). Four days after the replacement of the combs, bees continued preferring the treatment-odor feeder to the novel-odor feeder (H1: $\mathrm{G}=13.406, P<0.001, \mathrm{df}=1, \mathrm{~N}=$ 65; $\mathrm{H} 2: \mathrm{G}=19.289, P<0.001, \mathrm{df}=1, \mathrm{~N}=$ 209; G-Test goodness of fit; Fig. 1b). This effect was still found 8 days after the removal of all the combs in the LIO-treated colony $(\mathrm{H} 1$ : $\mathrm{G}=4.913, P=0.026, \mathrm{df}=1, \mathrm{~N}=184$; G-Test goodness of fit; Fig. 1c), but not in the PHEtreated colony $(\mathrm{H} 2: \mathrm{G}=0.758, P=0.383, \mathrm{df}=$ $1, \mathrm{~N}=132$; G-Test goodness of fit; Fig. 1c). No differences were detected in the last testing period, 11 days after the removal of the honey stores, in both treated colonies $(\mathrm{H} 1: \mathrm{G}=0.758$, $P=0.493, \mathrm{df}=1, \mathrm{~N}=173 ; \mathrm{H} 2: \mathrm{G}=0.758, P=$ 0.284 , df $=1, \mathrm{~N}=71 \mathrm{G}$-Test goodness of fit; Fig. 1d).

\subsection{Experiment 2 : Testing food choices in a scented-feeder vs. an unscented-feeder device}

Here, food preference was analyzed in time: before, during and after stimulation. In both the scented food and the scented environment, a strong preference for the unscented choice was observed before the stimulation (Fig. 2). Bias to LIO (as a novel odor) remained constant across time in both experiments. However, while the proportion of landings to PHE (stimulation odor) increased both during and after the offering of scented food (Fig. 2a), it decreased when PHE was exposed within the hive (Fig. 2c). In the first case we found statistical differences between the responses obtained before and after the stimulation $(\mathrm{G}=$ $10.180, P=0.006, \mathrm{df}=2, \mathrm{~N}=222$ ). In the second case, we also detected differences in the responses obtained before and after the stimulation $(\mathrm{G}=8.538, P=0.013, \mathrm{df}=2, \mathrm{~N}=335)$.

\section{DISCUSSION}

The present study showed that the olfactory information acquired either associated with food or exposed as volatile compounds in the colony environment biased the honeybee foraging decisions for several days. We showed that in-hive appetitive learning leads to a foraging preference lasting at least for four days after acquiring the odor information.

On the other hand, we demonstrated that floral scent not directly paired with food promotes the reduction in the number of visits to the scented feeder during the testing time. In both experiments, bees did not require the presence of scented food stores in the nest to prime the retrieval of the olfactory memory, since after replacing all the combs individual bees still transferred the information gained in the hive to the operant context of the testing devices.

Moreover, since the number of visits to the feeder scented with the same volatile exposed in the hive environment decreased with time, we excluded the possibility that the bias in food preferences found after the offering of scented food was due to a sensory priming process instead of a conditioning procedure (Schacter and Buckner, 1998; Giurfa, 2003).

\subsection{Scented food}

In experiment 1 rewarded olfactory experience lead to four and eight-day-memories depending on the odor used to scent the food (PHE or LIO, respectively). In a similar context however, Menzel (1968) found that (color) memory retention was able to last up to 13 days after acquisition if honeybees were prevented from foraging outside the hive. More recently, Beekman (2005) showed that none of the experienced bees could be reactivated to the scent of a past-profitable food source after ten days of foraging deprivation. Differences between our results and those may be explained by the access to natural food sources. In our study foragers were able to collect food outside the flight chamber, and then the memories established during the treatment may have been affected by novel experiences gained in the natural environment.

To prevent a confounding effect of natural food sources over the tested bees, we used a cross-fashioned design (i.e. the fact that the 


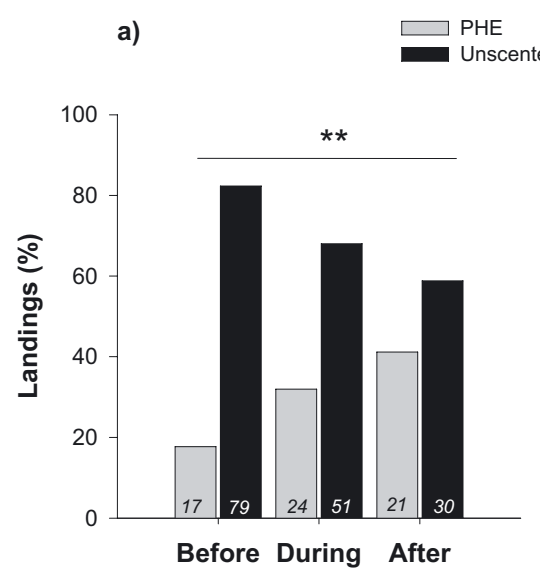

b)

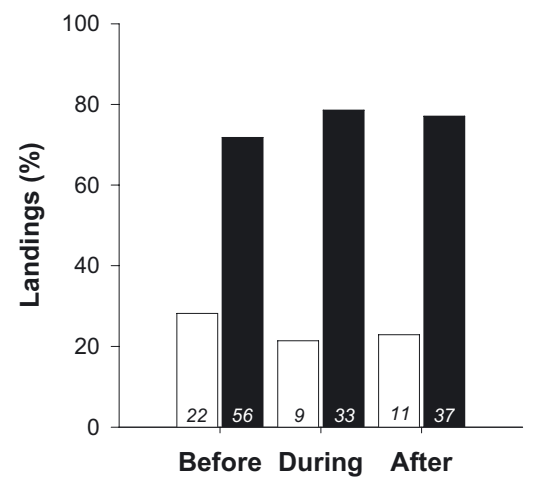

Offering of scented food

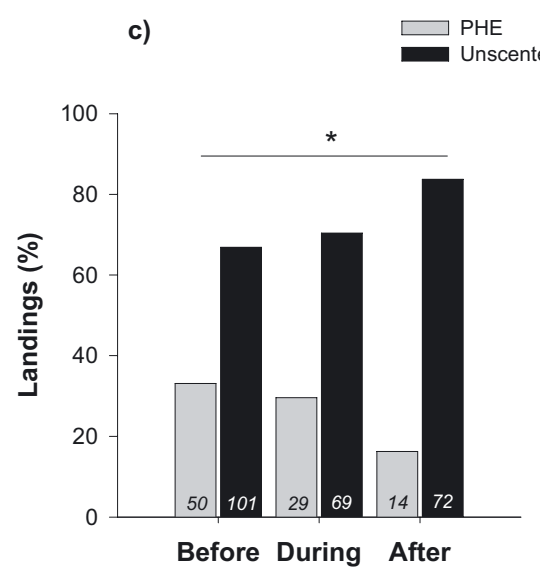

d) $\square$ UIO

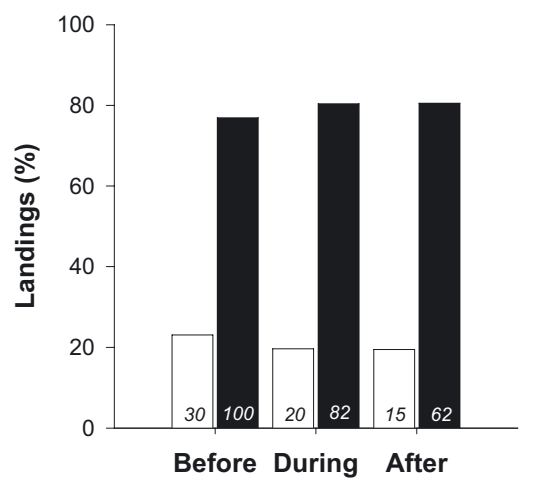

Odor in environment

Figure 2. Percentages of landings carried out by honeybees at each testing feeder for different times during the odor-experience experiment: before ( 2 and 1 days before the olfactory experience), during ( 2 and 4 days after initiating the odor experience, i.e. the odor source is presented inside the hive), and after the odor experience (three hours and 2 days after removing the odor source and replacing of all the honeycombs). Landings on the dual-choice device when a PHE-sugar solution was offered inside the hive: (a) PHE-feeder vs. unscented feeder, (b) LIO-feeder (novel odor) vs. unscented feeder. Landings on the dual-choice device when PHE was exposed in the hive environment: (c) PHE-feeder vs. unscented feeder, (d) LIO-feeder (novel odor) vs. unscented feeder. Landings for LIO are presented in white bars, for PHE in gray bars and for the unscented feeder in black bars. The number of bees landing on each feeder is shown at the bottom of each bar. Asterisks indicate statistical differences in G-Tests ( $* P<0.05$, ** $P<0.01$; see Results for details).

solution odor of one hive represented the novel odor of the other colony) that allowed us measuring both hives simultaneously. Thus, if floral odors brought back to the hives actually affect the performance of tested foragers, this should take place in a very similar way for both colonies.
Conspicuous asymmetries in retention performance between LIO and PHE found here have already been reported in honeybees (Smith, 1993; Sandoz et al., 2001) but also in bumblebees (Laloi et al., 2004) and moths (Daly et al., 2001), and might be related to the biological relevance of the stimuli. Although 
both LIO and PHE are typical floral scents, the first is much more common in the mellifera flora (Knudsen et al., 1993) and could have some potential communication value, as has been proposed for bumblebees (Laloi et al., 2004) and moths (Daly et al., 2001).

Preferences in the scented-food experiments evaluated in a two-scented-feeder device (Experiment 1) were also observed in a scented-feeder vs. unscented-feeder situation (Experiment 2b). Differences between each protocol might reside in the amount of information available in both alternatives of the choice device and their similarities with the immediately prior experience gained at the foraging site during training. In this sense, preferences in the two-scentedfeeder situation (where both testing feeders were different in the olfactory modality from the training feeder) seem to be guided by the odor-rewarded memories obtained in the hive. Conversely, preferences evaluated in a scented-feeder vs. unscented-feeder device, may strongly depend on the experience gained during training, since one of the options of the choice device perfectly matched with the prior searching image obtained at the foraging site a few minutes before.

\subsection{Scented environment}

The comparison between the testing procedures reported in Experiment 2 revealed that under a control situation or even after an olfactory conditioning, floral odors were not unequivocally chosen against an unscented alternative (Fig. 2). In our preliminary experiments (data not shown), bees from colonies with a scented environment were also tested in a two-scented-feeder device. Unfortunately, the number of landings on the testing feeders was extremely low and did not allow us to obtain a reasonable sample size to achieve conclusions. Somehow, the simultaneous presentation of the odors seems to prevent exposed bees from landing and made them abandon the device and return to the colony with empty loads.

The reduction in the number of visits to the feeder scented with the hive-exposed odor
(Fig. 2c) could not be explained just by the absence of pairing between the odor and a reward. No difference in the number of landings was found across time when a novel odor was presented in one of the feeders (Fig. 2d). Thus, we propose that non-associative learning might be responsible for driving the decreasing response after the olfactory exposure (Thorpe, 1963). This result thus opens the question whether a floral odor exposed as a volatile within the hive prevents the nectarforaging tasks towards this particular floral type in the field.

\section{ACKNOWLEDGEMENTS}

We are indebted to C. Grüter and two anonymous referees for their valuable comments and suggestions on an early version of this manuscript. We also thank A. Falibene and G. Ramírez for assistance during the testing phase. This study was supported by grants from ANPCYT (01-1155), University of Buenos Aires (X 077) and CONICET to WMF. We declare that our experiments comply with the current laws of the country in which they were performed.

Les odeurs florales perçues à l'intérieur de la colonie affectent les préférences à long terme des abeilles domestiques.

Apis mellifera / apprentissage olfactif / mémoire à long terme / comportement de butinage / choix / odeur florale

\footnotetext{
Zusammenfassung - Innerhalb des Bienenvolkes wahrgenommene Blütendüfte beeinflussen die langfristigen Sammelpräferenzen bei Honigbienen. Bei Honigbienen ist die Bewertung eines spezifischen Reizes als Anzeiger einer Belohnung stark von dem Kontext abhängig, in dem dieser wahrgenommen wurde (Sandoz et al., 2000; Gerber et al., 1996). Um das Sammelverhalten zu optimieren, lernen Honigbienen sowohl an der Sammelstelle als auch innerhalb des Volkes olfaktorische Blüteneigenschaften mit einer Belohnung $\mathrm{zu}$ assoziieren (z.B. von Frisch, 1923; Wenner et al., 1969). In neueren Untersuchungen konnten wir zeigen, dass assoziative Lernereignisse wie die obengenannten zur Ausbildung eines olfaktorischen Gedächtnisses führen, das dann wiederum dazu genutzt wird, den gelernten Duft in der Umgebung aufzufinden (Arenas et al., 2007). Hierbei zeigten Bienen mehrere Stunden nachdem sie
} 
mit duftender Nahrung behandelt worden waren eine Präferenz für diesen Duft. Dies war auch dann der Fall, wenn sie aus Völkern kamen, aus denen die Vorräte vollständig entfernt worden waren. Es war allerdings unbekannt, über welche Zeit hinweg diese Präferenz beibehalten wird. Daher boten wir den Bienen über vier Tage hinweg eine mit einem reinen Duft (Linalool oder Phenylacetaldehyde) versehene Zuckerlösung innerhalb des Bienenvolkes an. Danach wurden die Landeereignisse der Sammlerinnen in einer mit zwei verschiedenen Gerüchen markierten Fütterungseinrichtung außerhalb des Volkes registriert. Die Sammlerinnen zeigten eine Bevorzugung des zuvor in Umlauf gebrachten Futterduftes über vier Tage nach Entfernung aller Futtervorräte aus dem Bienenvolk (Abb. 1). Einer der Düfte (Linalool) beeinflusste die Landeereignisse über bis zu 8 Tage nach Entfernung aller Futtervorräte (Abb. 1).

Da das Anbieten bedufteten Futters in sich selbst ein Sinnesereignis darstellt, das das Sammelverhalten beeinflussen könnte (z.B. durch sensorisches "priming"), führten wir in zweites Experiment durch. In diesem wollten wir herausfinden, ob die Futterpräferenzen auch dann bestanden wenn der Duft in der Lösung nur verdünnt vorhanden war oder innerhalb des Volkes angeboten wurde, aber nicht in der Futterlösung. Dann untersuchten wir $\mathrm{zu}$ verschiedenen Zeiten (vor, während und nach der Geruchserfahrung), ob die Sammlerinnen den bereits wahrgenommenen Geruch gegenüber einer geruchslosen Wahlalternative bevorzugten. Wir beobachteten eine Verringerung in der Anzahl der Bienen, die auf dem Fütterer mit bekanntem Geruch landeten, während die Landungen auf dem Fütterer mit einem neuen Geruch gleich blieben. Hierdurch zeigten wir, dass die Beeinflussung der Futterwahl bei Honigbienen von mehreren Faktoren abhängt: (i) Die geruchlichen Erfahrungen innerhalb des Volkes bauen Gedächtnisinhalte auf, die über lange Zeit bestehen bleiben, auch wenn die Bienen Sammelzugang zu natürlichen Futterquellen haben. (ii) Die unbelohnten Geruchserfahrungen innerhalb des Bienenvolkes beeinflussen die Futterwahl außerhalb des Bienenvolkes im entgegengesetzten Sinne wie bei i). (iii) Je nach angewendeter Methodik können daher unterschiedliche Ergebnisse resultieren.

\section{Apis mellifera / Honigbienen / Geruchslernen / Langzeitgedächtnis / Futterwahl}

\section{REFERENCES}

Arenas A., Farina W.F. (2008) Age and rearing environment interact in the retention of early olfactory memories in honeybees, J. Comp. Physiol. A 194, 629-640.
Arenas A., Fernández V.M., Farina W.M. (2007) Floral odor learning within the hive affects honeybees' foraging decisions, Naturwissenschaften 94, 218 222.

Balsam P.D. (1985) The function of context in learning and performances, in: Balsam P.D., Tomie A. (Eds.), Context and Learning. Hillsdale, L. Erlbaum, New Jersey, pp. 1-22.

Beekman M. (2005) How long will honey bees (Apis mellifera $\mathrm{L}$.) be stimulated by scent to revisit pastprofitable forage sites? J. Comp. Physiol. A 191, 1115-1120.

Daly K.C., Durtschi M.L., Smith B.H. (2001). Olfactory-based discrimination in the moth, Manduca sexta, J. Insect Physiol. 47, 375-384.

Dornhaus A., Chittka L. (1999) Evolutionary origins of bee dances, Nature 401, 38 .

Farina W.M., Grüter C., Diaz P.C. (2005) Social learning of floral odours within the honeybee hive, Proc. R. Soc. B 272, 1923-1928.

Farina W.M., Grüter C., Acosta L.E., Mc Cabe S. (2007) Honeybees learn floral odors while receiving nectar from foragers within the hive, Naturwissenschaften 94, 55-60.

Frisch K. von (1923) Über die "Sprache" der Bienen, Zool Jahrb (Zoologie und Physiologie) 40, 1-186.

Gerber B., Geberzahn N., Hellstern F., Klein J., Kowalksy O., Wüstenberg D., Menzel R. (1996) Honey bees transfer olfactory memories established during flower visits to a proboscis extension paradigm in the laboratory, Anim. Behav. 52, 1079-1085.

Gil M., De Marco R.J. (2005) Olfactory learning by means of trophallaxis in Apis mellifera, J. Exp. Biol. 208, 671-680.

Giurfa M. (2003) Cognitive neurothology: dissecting non-elemental learning in a honeybee brain, Curr. Opin. Neurobiol. 13, 726-735.

Grüter C., Acosta L.E., Farina W.M. (2006) Propagation of olfactory information within the honeybee hive, Behav. Ecol. Sociobiol. 60, $707-715$.

Jandt J.M., Jeanne R.L. (2005) German yellowjacket (Vespula germanica) foragers use odors inside the nest to find carbohydrate food sources, Ethology 111, 641-651.

Knudsen J.T., Tollsten L., Bergstrom L.G. (1993) Floral scents - A checklist of volatile compounds isolated by headspace techniques, Phytochemistry 33, 253-280.

Laloi D., Pham-Delègue M.H. (2004) Bumble Bees Show Asymmetrical Discrimination Between Two Odors in a Classical Conditioning Procedure, J. Insect Behav. 17, 3, 385-396.

Menzel R. (1968) Das Gedächtnis der Honigbiene für Spektralfarben. I. Kurzzeitiges und langzeitiges Behalten, Z. Vergl. Physiol. 60, 82-102. 
Menzel R. (1999) Memory dynamics in the honeybee, J. Comp. Physiol. A 185, 323-340.

Pham-Delègue M.H., Roger B., Charles R., Masson C. (1990) Effet d'une pré-exposition olfactive sur un comportement d'orientation en olfactomètre dynamique à quatre voies chez l'abeille (Apis mellifera L.), Insectes Soc. 37, 181-187.

Rescorla R.A., Durlach P.J., Grau J.W. (1985) Context learning in Pavlovian conditioning, in: Balsam P.D., Tomie A. (Eds.), Context and Learning. Hillsdale, L. Erlbaum, New Jersey, pp. 23-56.

Roces F. (1990) Olfactory conditioning during the recruitment process in a leaf-cutting ant, Oecologia $83,261-262$.

Sandoz J.C., Laloi D., Odoux J.F., Pham-Delègue M.H. (2000) Olfactory information transfer in the honeybee: Compared efficiency of classical conditioning and early exposure, Anim. Behav. 59, $1025-1034$.
Sandoz J.C., Pham-Delègue M.H., Renou M., Wadhams L.J. (2001) Asymmetrical generalisation between pheromonal and floral odours in appetitive olfactory conditioning of the honey bee (Apis mellifera L.), J. Comp. Physiol. A 187, 559-568.

Schacter D.L., Buckner R.L. (1998) Priming and the brain, Neuron 20, 185-195.

Smith B.H. (1993). Merging mechanism and adaptation: An ethological approach to learning and generalization, in: Papaj D.R., Lewis A.C. (Eds.), Insect Learning: Ecological and Evolutionary Perspectives, Chapman and Hall, New York, pp. $126-157$.

Sokal R.R., Rohlf F.J. (1995) Biometry: The Principles and Practice of Statistics in Biological Research, W. H. Freeman and Co., New York, pp. 715-724.

Thorpe W.H. (1963) Learning and instinct in animals, 1st ed., London, Methuen, UK.

Wenner A.M., Wells P.H., Johnson D.L. (1969) Honey bee recruitment to food sources: olfaction or language? Science 164, 84-86. 